\title{
REKOGNISI DALAM MEREPRESENTASIKAN SIMBOL TURUNAN PARSIAL SEBAGAI METONYMY DAN \\ METAPHOR
}

\author{
Zukhrufurrohmah, Octavina Rizky Utami Putri \\ FKIP Universitas Muhammadiyah Malang, Indonesia \\ Email: zukhrufurrohmah@umm.ac.id
}

\begin{abstract}
ABSTRAK
Penelitian ini bertujuan untuk mendeskripsikan kemampuan mahasiswa Teknik Sipil dalam merepresentasikan simbol sebagai metonymy dan metaphor melalui penyelesaian masalah Turunan Parsial. Instrumen penelitian yang digunakan adalah lembar observasi pembelajaran dan lembar worksheet berciri representasi matematis. Obervasi pembelajaran dilakukan ketika kegiatan pembelajaran dengan menggunakan worksheet berciri representasi matematis dilaksanakan. Worksheet berciri representasi matematis yang disajikan pada masalah mengenai materi Turunan Parsial yang mengarahkan dan membantu mahasiswa mengenal representasi simbol pada materi Turunan Parsial sebagai metonymy dan metaphor. Pengerjaan worksheet dilakukan mahasiswa setelah kegiatan refleksi dan diskusi kelas mengenai materi yang akan dipelajari dilaksanakan. Hasil lembar observasi pembelajaran berupa rangkaian kegiatan dalam pembelajaran dan temuan-temuan diskusi (tanya-jawab) antara dosen dan mahasiswa mengenai materi Turunan Parsial. Sedangkan hasil pengerjaan worksheet digunakan untuk mengukur kemampuan mahasiswa dalam merepresentasikan simbol pada turunan parsial sebagai metonymy dan metaphor. Hasil pengerjaan worksheet dianalisis berdasar indikator representasi yang telah ditentukan. Hasil penelitian menunjukkan bahwa mahasiswa Teknik Sipil kurang baik dalam merepresentasikan simbol turunan parsial sebagai metonymy dan metaphor. Kurangnya kemampuan mahasiswa dalam merepresentasikan simbol sebagai metonymy tampak dari kesalahan mahasiswa dalam mengelompokkan simbol turunan parsial dan kesalahan dalam menggunakan dan mengenali simbol turunan parsial dalam penyelesaian masalah. Kurangnya kemampuan mahasiswa dalam merepresentasikan simbol sebgaai metaphor tampak dari kesalahan mahasiswa dalam memaknai simbol turunan parsial ketika fungsi $f$ diturunkan terhadap variabel $x$ maupun $y$, dan kesalahan dalam menggunakan simbol turunan parsial dalam menyelesaikan masalah.
\end{abstract}

Kata Kunci: Representasi; Symbol; Turunan Parsial; Metonymy; Metaphor.

\begin{abstract}
This research aimed to describe the ability of Civil Engineering students to represent symbols as metonymy and metaphor through solving the partial derivative problem. The research instruments used were learning observation sheets and worksheets were characterized by mathematical representations. Learning observation was carried out when learning activities by using worksheets characterized by mathematical representation were carried out. Worksheets characterized by mathematical representations were presented on the problem of Partial Derivative material that directs and helps students to recognize the representation of symbols on Partial Derivative material as metonymy and metaphor. Worksheets were carried out by students after the reflection activities and class discussions regarding the material to be studied were carried out. The results of the learning observation sheet were a series of activities in learning and the findings of discussion (question and answer) between lecturers and students regarding Partial Derivative material. While the results of the worksheet were used to measure the ability of students to represent symbols on partial derivatives as metonymy and metaphor. The results of the worksheet were analyzed based on the specified representation indicators. The results showed that Civil Engineering students were not good at representing partial derivative symbols as metonymies and
\end{abstract}


metaphors. The lack of students 'ability to represent symbols as metonymy appears from students' mistakes in classifying partial derivative symbols and errors in using and recognizing partial derivative symbols in solving the problem. The lack of students 'ability to represent symbols as metaphors can be seen from students' errors in interpreting partial symbols when $\mathrm{f}$ functions are derived from $\mathrm{x}$ or $\mathrm{y}$ variables, and errors in using partial derivative symbols in solving problems.

Keywords: Representations; Symbols; Partial Derivatives; Metonymy; Metaphor.

\section{PENDAHULUAN}

Bentuk interpretasi dari ide matematika sebagai upaya dalam menyelesaikan suatu masalah dapat disajikan melalui representasi matematis (Astuti, 2017; Hutagaol, 2013; Sabirin, 2014). Representasi matematis dapat disajikan dalam bentuk verbal, tulisan, tabel, grafik, gambar, serta simbol (Lestari \& Yudhanegara, 2017; Sabirin, 2014). Representasi matematis banyak berkaitan dengan penyajian simbol matematis (Leibovich \& Ansari, 2016; Stalnaker \& Zanibbi, 2015). Representasi matematis secara simbolik dinyatakan sebagai pernyataan matematis atau simbol aljabar (Astuti, 2017). Analisis representasi matematis dapat mendeteksi kesulitan dalam belajar matematika (Jitendra, Nelson, Pulles, Kiss, \& Houseworth, 2016).

Representasi matematis secara simbolik erat kaitannya dengan rekognisi simbol. Rekognisi terhadap simbol matematis dapat terjadi ketika mahasiswa menyadari simbol yang digunakan terkait dengan masalah yang diberikan (Mandasari, 2018). Rekognisi simbol matematis memuat penggunaan simbol yang benar. Kesalahan penggunaan simbol memerlukan identifikasi kesalahan. Rekognisi simbol matematis dapat dilakukan dengan cara (1) mengelompokkan simbol-simbol matematis, dan (2) mengidentifikasi kesalahan simbol (JulcaAguilar, Hirata, Viard-Gaudin, Mouchere, \& Medjkoune, 2014).

Berdasarkan pengamatan terhadap mahasiswa Teknik Sipil dalam kegiatan diskusi klasikal pada perkuliahan Kalkulus, diperoleh bahwa representasi matematis mahasiswa kurang baik, terutama dalam menyajikan simbol matematis. $12 \%$ mahasiswa dapat menentukan jawaban akhir dari pertanyaan soal turunan dengan benar, namun salah dalam menggunakan simbol turunan, sedangkan mahasiswa lainnya tidak memberikan solusi. Sebagai contoh dalam menentukan turunan parsial fungsi dua variabel, misalkan diberikan $f(x, y)=3 x^{2}+4 y$. 
Mahasiswa memberikan solusi $f^{\prime}(x, y)=6 x$ dengan alasan turunan fungsi $f$ terhadap $x$ dan menganggap $4 y$ suatu konstanta. Simbol $f^{\prime}(x, y)$ yang diberikan oleh mahasiswa mengacu pada simbol turunan fungsi satu variabel $f^{\prime}(x)$ dan membawanya pada turunan fungsi dua variabel. Kesalahan penggunaan simbol turunan fungsi dua variabel tidak disadari oleh mahasiswa. Mahasiswa mementingkan prosedur penyelesaian, tanpa memperhatikan simbol yang digunakan. Dalam hal ini, dosen memberikan scaffolding bahwa jika $f^{\prime}(x, y)=$ $6 x$ turunan parsial terhadap $x$, bagaimana turunan parsial terhadap $y$ ? Dosen menekankan arti parsial terhadap mahasiswa yang berarti sebagian, dan membimbing mahasiswa untuk mengidentifikasi kesalahan simbol pada $f^{\prime}(x, y)=6 x$. Mahasiswa dapat menyadari kesalahannya setelah dosen memberikan scaffolding, sehingga mahasiswa merevisi $f^{\prime}(x, y)=6 x$ menjadi $f_{x}(x, y)=6 x$ dan menentukan $f_{y}(x, y)=4$. Kesalahan penggunaan simbol turunan parsial oleh mahasiswa, disebabkan oleh analogi mahasiswa bahwa simbol turunan fungsi satu variabel $f(x)$ yaitu $f^{\prime}(x)$ dapat digunakan pada turunan fungsi dua variabel.

Bentuk analogi khusus yang sering menjadi pusat dalam mengkonstruksi suatu makna disebut dengan metaphor. Penandaan suatu informasi disajikan dalam suatu tanda khusus, dalam hal ini simbol, disebut dengan metonymy (Presmeg, 2013). Metonymy dan methapor terlibat dalam sistem penandaan/penyimbolan saat seseorang menemukan simbol baru dalam proses pembelajaran matematika (Malviya, 2019; Presmeg, 2013). Metonymy dan methapor bukan hal yang terpisah, melainkan saling terkait, terutama pada usaha seseorang dalam memahami simbol matematika yang sama dalam konteks yang berbeda (Malviya, 2019).

Penelitian tentang simbol sebagai metonymy dan metaphor telah dilakukan sebelumnya, yang dikaji dalam sudut pandang sosiologi. Penelitian tersebut membahas tentang keterlibatan metonymy dan metaphor dalam pemaknaan simbol matematis yang dilakukan siswa dalam pembelajaran secara online dan di kelas (Malviya, 2019). Penelitian lainnya terkait keterlibatan metonymy sebagai rantai penanda dan metaphor sebagai penurunan ke makna dalam proses penalaran oleh Presmeg (2013). 
Berdasarkan latar belakang di atas, penelitian ini membahas lebih mendalam mengenai keterlibatan metonymy dan metaphor dalam rekognisi penyajian simbol turunan parsial. Oleh karena itu, rumusan masalah dalam penelitian ini adalah bagaimana rekognisi mahasiswa Teknik Sipil terhadap penyimbolan turunan parsial sebagai metonymy dan metaphor berdasarkan kemampuan representasi matematis simbolik. Penelitian ini bertujuan untuk menganalisis dan mendeskripsikan rekognisi mahasiswa Teknik Sipil terhadap penyimbolan turunan parsial sebagai metonymy dan metaphor berdasarkan kemampuan representasi matematis simbolik.

Fokus penelitian ini adalah mendeskripsikan kemampuan rekognisi mahasiswa dalam merepresentasikan simbol turunan parsial sebagai metonymy dan metaphor. Penelitian ini dipandang perlu sebagai penelitian pemula untuk melihat lebih dalam sudut pandang mahasiswa mengenai pemaknaan simbol matematika sehingga dapat direncanakan perbaikan pembelajaran. Batasan penelitian ini adalah rekognisi simbol pada materi fungsi dua variabel atau lebih, turunan parsial dan turunan parsial tingkat tingg dengan subjek penelitian 1 kelas yang berjumlah 41 mahasiswa Jurusan Teknik Sipil Universitas Muhammadiyah Malang.

\section{METODE}

Pada penelitian ini, dipilih jenis penelitian deskriptif dengan pendekatan kualitatif. Langkah penelitian terdiri dari 6 langkah: 1) identifikasi permasalahan penelitian, 2) tinjauan pustaka, 3) penetapan maksud penelitian, 4) pengumpulan data, 5) analisis dan interpretasi data, dan 6) pelaporan dan evaluasi penelitian. Identifikasi masalah penelitian dilakukan dengan melakukan kegiatan evaluasi pada kegiatan pembelajaran dan hasil belajar mahasiswa pada matakuliah kalkulus II. Berdasar temuan lapangan, ditetapkan bahwa subjek penelitian ini adalah Mahasiswa Jurusan Teknik Sipil Universitas Muhammadiyah Malang yang berada pada semester II. Jumlah subjek penelitian adalah 41 Mahasiswa Teknik Sipil kelas A yang sedang menempuh Matakuliah Kalkulus II.

Pengumpulan data penelitian dilakukan melalui lembar observasi pembelajaran dan worksheet. Observasi dilaksanakan ketika pembelajaran berlangsung, yaitu diawali dengan siswa menyelesaikan soal mengenai materi yang 
akan dipelajari dengan mencari referensi dari berbagai sumber, kemudian dosen bersama mahasiswa berdiskusi mengenai pokok materi yang dipelajari dan membahas permasalahan pada tugas rangkuman. Kegiatan diskusi kelas dilanjutkan dengan diskusi kelompok dimana mahasiswa diminta menyelesaikan permasalahan pada worksheet dan kegiatan pembelajaran diakhiri dengan refleksi, yaitu mahasiswa menyelesaikan 2 atau 3 soal terkait materi yang dipelajari. Lembar Observasi berupa catatan lapangan yang terdiri dari indentitas tanggal obervasi, kegiatan dosen, dan respon/kegiatan mahasiswa terhadap tindakan dosen dan kegiatan pembelajaran yang dilaksanakan. Tujuan observasi pembelajaran adalah melihat respon mahasiswa dan dosen dalam mengguankan worksheet, melihat keterlaksanaan kegiatan pembelajaran dan mencatat temuan-temuan dalam pembelajaran. Worksheet diberikan kepada setiap mahasiswa namun dikerjakan dengan berdiskusi bersama kelompok yang telah ditentukan. Worksheet dibuat dengan memberikan permasalahan pada mahasiswa untuk terlebih dahulu mengenali simbol-simbol pada turunan parsial, kemudian mengenali perbedaan simbol-simbol yang ada pada turunan parsial dan kemduian menyelesaikan soal turunan parsial. Worksheet berciri representasi matematis juga memuat soal pada bagian refreksi untuk menguji kemampuan mahasiswa dalam menyelesaikan soal turunan parsial menggunakan representasi matematis sebagai metonymy dan metaphor. Permasalahan pada worksheet yang diberikan memuat indikator mengenai pengelompokan simbol dan identifikasi simbol. Kisi-kisi permasalahan pada worksheet dituliskan pada Tabel 1 berikut.

$\underline{\text { Tabel } 1 \text { Kisi-kisi Permasalahan untuk Mengukur Kemampuan Rekognisi Matematis }}$ Indikator Kisi-kisi

\begin{tabular}{lrl}
\hline $\begin{array}{l}\text { Mengelompokkan } \\
\text { simbol }\end{array}$ & $\begin{array}{l}\text { 1. Mengelompokkan simbol turunan sebagai penandaan simbol } \\
\text { matematika }\end{array}$ & $\begin{array}{l}\text { 2. Mengelompokkan simbol turunan dengan memberikan makna } \\
\text { simbol turunan parsial (metaphor) }\end{array}$ \\
$\begin{array}{l}\text { Menyelesaikan } \\
\text { soal turunan }\end{array}$ & $\begin{array}{l}\text { 1. Menyelesaikan soal turunan parsial dengan mengenali } \\
\text { penandaan simbol turunan parsial (metonymy) }\end{array}$ \\
$\begin{array}{l}\text { parsial dengan } \\
\text { memaknai simbol } \\
\text { matematika atau } \\
\text { mengenali }\end{array}$ & $\begin{array}{l}\text { 2. Menyelesaikan soal turunan parsial dengan memaknai simbol } \\
\text { turunan parsial (metaphor) } \\
\text { penanda simbol }\end{array}$ & \\
\hline
\end{tabular}

JINoP (Jurnal Inovasi Pembelajaran),Volume 5, Nomor 2, November 2019, hal 214-226 
Analisis data pada lembar observasi dilakukan dengan langkah: a) memilah perbedaan-perbedaan antara rencana pelaksanaan pembelajaran dengan kegiatan pembelajaran yang dilakukan dosen, b) memilah temuan-temuan dalam pembelajaran berupa respon atau pertanyaan mahasiswa kepada dosen terkait turunan parsial atau kegiatan pada worksheet, c) menyimpulkan mengenai temuantemuan pembelajaran dan keterlaksanaan pembelajaran. Analisis data pada worskheet dilakukan dengan langkah: a) memberi tanda kesalahan pengelompokan yang dilakukan mahasiswa, b) memberikan tanda pada kesalahan-kesalahan memaknai simbol dan kesalahan menuliskan simbol, c) mengelompokkan kesalahan-kesalahan pengelompokan maupun pemaknaan yang dilakukan mahasiswa, kemudian d) menyajikan dan menganalisis kesalahan-kesalahan yang dilakukan mahasiswa.

\section{HASIL DAN PEMBAHASAN}

Data diperoleh melalui hasil pengerjaan worksheet yang diberikan kepada mahasiswa. Permasalahan pada worksheet memuat indikator untuk mengukur kemampuan mahasiswa dalam merepresentasikan simbol turunan parsial sebagai metonymy dan metaphor. Kemampuan representasi diukur sesuai dengan indikator yang telah ditetapkan yaitu mengelompokkan simbol matematika dan menyelesaikan soal turunan parsial dengan memaknai simbol matematika atau mengenali penanda simbol. Berikut disampaikan deskripsi kemampuan mahasiswa berdasar indikator yang telah ditentukan.

\section{Mengelompokkan simbol turunan sebagai metonymy}

Pengelompokkan simbol matematis dilakukan dengan memilih manakah simbol-simbol yang merupakan simbol turunan fungsi dua variabel dan manakah yang bukan serta memberikan makna simbol turunan fungsi dua variabel yang ditemukan. Hasil pengerjaan soal menunjukkan sebagian besar mahasiswa dalam satu kelas dapat dengan tepat mengelompokkan simbol turunan parsial (turunan fungsi lebih dari dua variabel). Kesalahan mahasiswa dalam mengelompokkan simbol turunan parsial adalah ketika menemukan simbol $D_{x}$. Beberapa mahasiswa mengelompokkan simbol $D_{x}$ sebagai simbol turunan parsial. Hal ini dikarenakan 
mahasiswa jarang menemukan dan menggunakan simbol $D_{x}$ dalam menyelesaikan turunan suatu fungsi satu variabel, sehingga sebagian siswa menduga simbol $D_{x}$ sebagai simbol turunan parsial. Gambar 1 menunjukkan kesalahan mahasiswa dalam mengelompokkan simbol $D_{x}$ sebagai simbol turunan parsial.

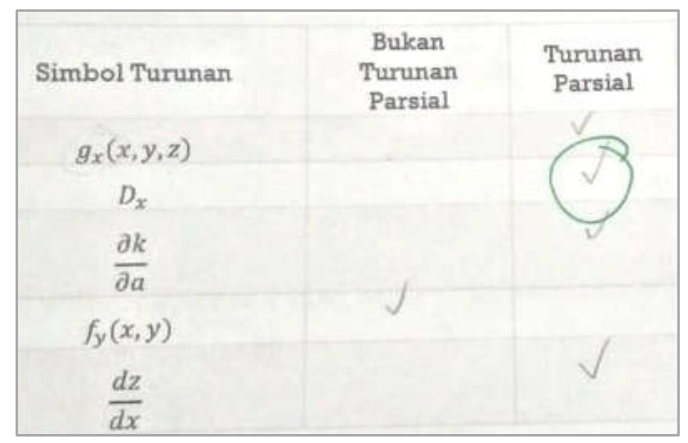

Gambar 1. Kesalahan Mahasiswa Mengelompokkan Simbol $D_{x}$ sebagai Simbol Turunan Parsial

\section{Mengelompokkan simbol turunan sebagai methaphor}

Pemaknaan simbol dilakukan dengan baik oleh sebagian besar mahasiswa. Mahasiswa dapat memaknai simbol $f_{x}$ sebagai simbol turunan parsial tingkat satu terhadap variabel $x$. Serta memaknai simbol $\frac{\partial f(x, y)}{\partial x}$ sebagai simbol turunan fungsi dua variabel $(x, y)$ terhadap variabel $x$. Kesalahan siswa dalam memaknai simbol terletak pada pemaknaan simbol $D_{x}$. Sebagian siswa memaknai sebagai simbol $D_{x}$ sebagai simbol turunan parsial. Gambar 2 berikut menunjukkan kesalahan pemaknaan mahasiswa pada simbol $D_{x}$.

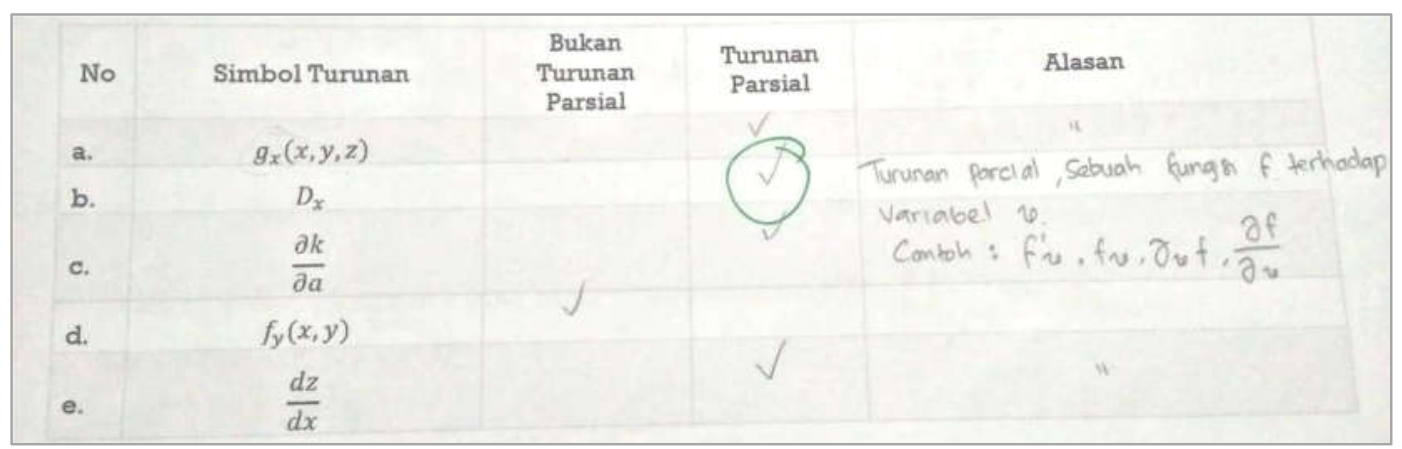

Gambar 2. Kesalahan pada Pemaknaan Simbol $D_{x}$ sebagai Simbol Turunan Parsial Menyelesaikan soal turunan parsial dengan memaknai simbol matematika atau mengenali penanda simbol sebagai metonymy.

Kesalahan penyelesaian turunan parsial menggunakan representasi simbolik dibagi menjadi tiga jenis kesalahan. Jenis kesalahan pertama adalah kesalahan 
mahasiswa merepresentasikan simbol turunan parsial namun benar menentukan hasil penyelesaian turunan parsial. Kesalahan kedua adalah kesalahan mahasiswa dalam menyelesaikan soal turunan parsial namun benar dalam merepresentasikan simbol turunan parsial. Kesalahan ketiga adalah kesalahan mahasiswa dalam merepresentasikan simbol turunan parsial dan menyelesaikan soal yang diberikan.

Kesalahan jenis pertama dilakukan 10\% mahasiswa. Mahasiswa menuliskan simbol turunan parsial menggunakan simbol turunan satu variabel. Mahasiswa menuliskan $\frac{d f}{d x}$ sebagai simbol turunan parsial yang seharusnya dituliskan menggunakan notasi $d o(\partial)$. Kesalahan yang dilakukan mahasiswa disebabkan karena terbiasanya menggunakan simbol diferensial satu variabel dibandingkan simbol $d o(\partial)$. Gambar 3 berikut menunjukkan kesalahan siswa pada jenis pertama.

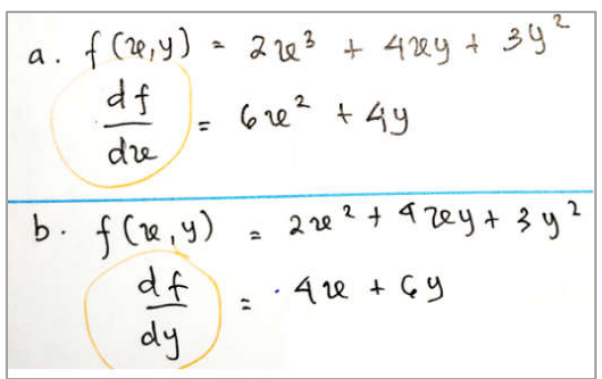

Gambar 3. Mahasiswa Salah dalam Merepresentasikan Simbol Turunan Parsial Namun Benar Menentukan Hasil Turunan Parsial

Kesalahan dalam menentukan hasil turunan parsial namun benar menuliskan simbol turunan parsial dilakukan 5\% mahasiswa. Hal ini terjadi karena mahasiswa masih bingung menghadapi variabel yang banyak dan letaknya berdampingan. Penyebab lainnya dalah ketidaktelitian mahasiswa dalam menentukan turunan parsial. Gambar 4 berikut menunjukkan hasil pekerjaan mahasiswa yang melakukan kesalahan pada menentukan hasil turunan parsial namun benar dalam menuliskan simbol turunan parsial.

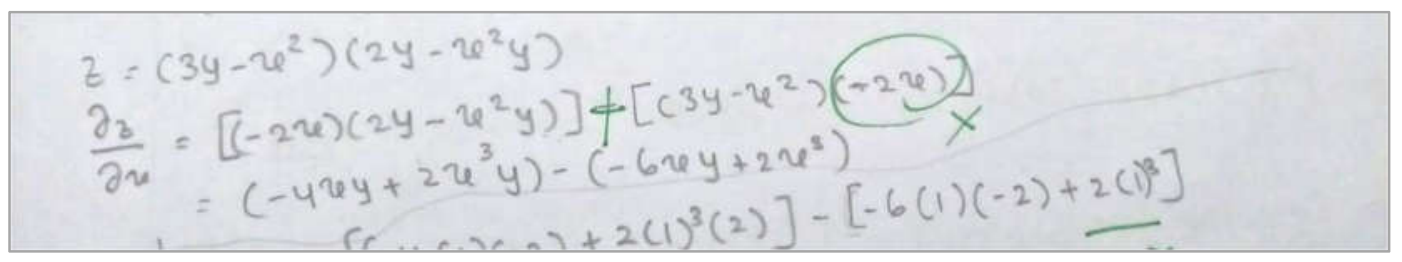

Gambar 4. Hasil Pekerjaan Mahasiswa yang Melakukan Kesalahan pada Menentukan Hasil Turunan Parsial Namun Benar dalam Menuliskan

Zukhrufurrohmah, Octavina Rizky Utami Putri, Rekognisi Dalam Merepresentasikan Simbol Turunan Parsial Sebagai Metonymy dan Metaphor 
Simbol Turunan Parsial

Kesalahan jenis ketiga yang dilakukan mahasiswa adalah kesalahan mahasiswa dalam merepresentasikan simbol turunan parsial dan menyelesaikan soal yang diberikan. Kesalahan jenis ketiga dilakukan mahasiswa karena tidak memahami konsep turunan parsial dan tidak memperhatikan simbol turunan parsial berbeda dengan simbol turunan satu fariabel. Gambar 5 di bawah ini menunjukkan kesalahan penulisan simbol mahasiswa dalam menuliskan simbol turunan parsial dan menentukan hasil turunan parsial. Mahasiswa menuliskan simbol turunan parsial dengan simbol petik atas.

$$
\begin{aligned}
& f(x, y)=x^{2}+y^{2} \\
& f^{\prime}(x, y)=2 x+2 y
\end{aligned}
$$

\section{Gambar 5. Kesalahan Mahasiswa dalam Menuliskan Simbol Turunan Parsial dan Menentukan Hasil Turunan Parsial}

Temuan di atas relevan dengan penelitian sebelumnya. Kesalahan dalam mengklasifikasikan simbol masih dilakukan oleh mahasiswa. Hal ini disebabkan oleh kurangnya pemahaman konsep mahasiswa pada suatu materi yang dipelajari. Mahasiswa menggunakan intuisi dan pengalaman sebelumnya dalam menyelesaikan permasalahan, tanpa memahami konsep materi yang dipelajari (Arvianto, 2017). Ketika mahasiswa dapat mengklasifikasikan kategori ke dalam berbagai kelompok, terjadilah suatu abstraksi matematis. Hal ini merupakan proses penggambaran situasi tertentu ke dalam suatu konsep yang dipikirkan melalui suatu konstruksi. Sehingga, mahasiswa dapat mengkonstruksi konsep melalui simbol matematis (Suryana, 2012).

\section{Menyelesaikan soal turunan parsial dengan memaknai simbol matematika atau mengenali penanda simbol sebagai metaphor}

Penyelesaian masalah diawali dengan memahami masalah. Pada permasalahan menentukan turunan parsial, mahasiswa dihadapkan pada representasi verbal dan representasi simbolik. Permasalahan yang diberikan diantaranya ditunjuk pada Gambar 6. Gambar 6 menunjukkan permasalahan yang disajikan dalam representasi verbal. Pada permasalahan ini mahasiswa diminta 
memahami apa yang diminta oleh soal. Mahasiswa harus merepresentasikan permasalahan dalam bentuk representasi simbolik terlebih dahulu untuk menyelesaikan permasalahan tersebut.

Selesaikan soal-soal turunan parsial berikut dengan menggunakan simbol yang benar!

1. Jika $f(x, y)=2 x^{3}+2 y^{3}$, berikan penjelasan untuk menyelidiki apalkah

a. Turunan parsial pertama $f$ terhadap $x$ sama dengan turunan parsial pertama $f$ terhadap $y$.

b. Turunan parsial pertama $f$ terhadap $x$ saat $(-1,2)$ sama dengan turunan parsial pertama $f$ terhadap $y$ saat $(2,-1)$.

\section{Gambar 6. Sajian Soal dalam representasi verbal}

Gambar 7 menunjukkan kesalahan siswa dalam memahami permasalahan yang diberikan. Kesalahan ini diikuti dengan kesalahan menyelesaikan permasalahan yang diberikan.

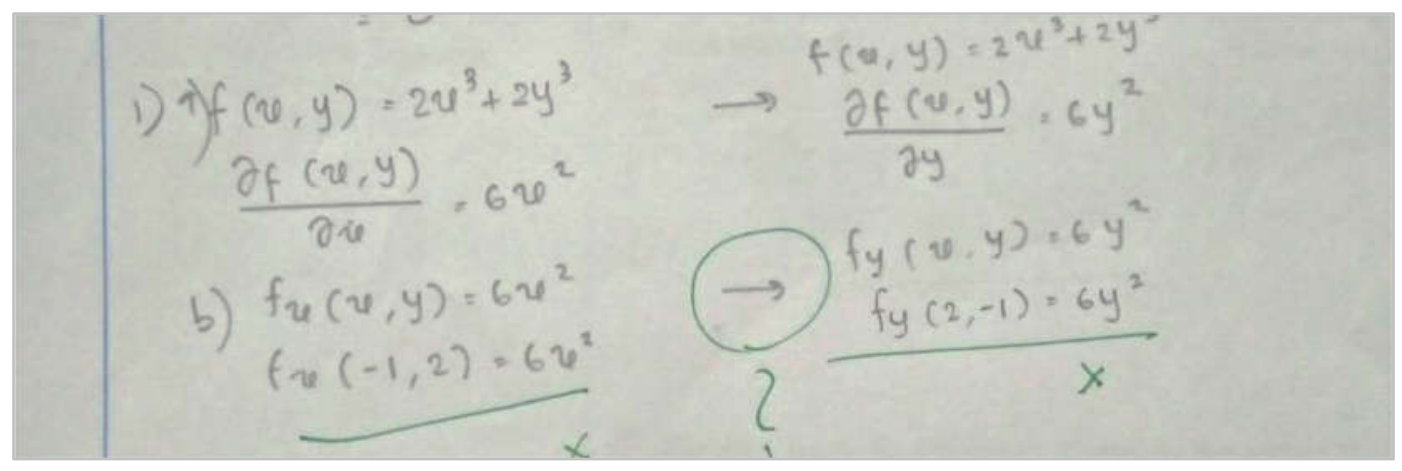

Gambar 7. Kesalahan siswa menjawab permasalahan pada soal $1 \mathrm{~b}$

Permasalahan kedua yang diberikan pada mahasiswa berbentuk representasi simbolik dimana mahasiswa diminta untuk menentukan hasil dari simbol yang diberikan. Bentuk permasalahan yang diberikan pada mahasiswa disajikan pada Gambar 8. Mahasiswa harus dapat memahami simbol yang dimaksud untuk menentukan hasil turunan parsial yang diminta.

2. Selidiki apakah $\left.\frac{\partial z}{\partial x}\right|_{(0,1)}=\left.\frac{\partial z}{\partial y}\right|_{(N I M, 1)}$,jika $f(x, y)=\left(2 x^{3}-3 x y\right)^{4} !$

\section{Gambar 8. Sajian Permasalahan dalam Representasi Simbolik}

Kesalahan siswa dalam memahami representasi simbolik yang diberikan pada permasalahan merupakan kesalahan dalam rekognisi simbol matematika. Kesalahan memahami simbol dapat terjadi karena mahasiswa tidak mengetahui 
simbol yang diberikan. Gambar 9 menunjukkan kesalahan siswa dalam menjawab permasalahan dengan menggunakan representasi simbol yang tidak tepat. Mahasiswa salah menuliskan simbol turunan parsial ditandai dengan warna kuning. Mahasiswa juga melakukan kesalahan perhitungan yang ditandai dengan tanda biru.

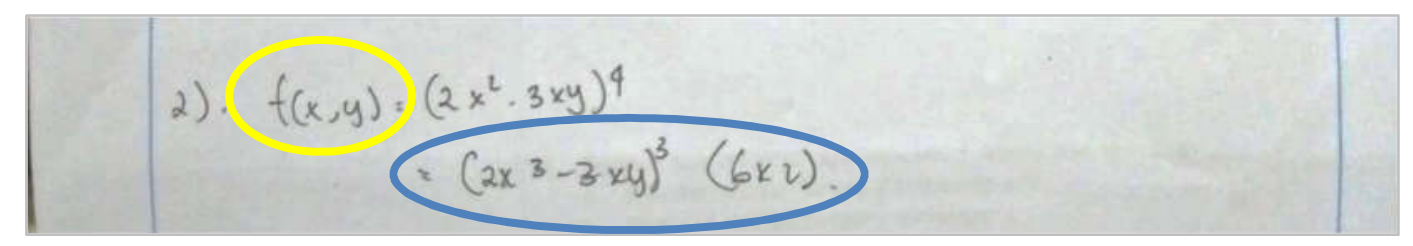

Gambar 9. Kesalahan Siswa Menentukan Turunan Parsial dengan Bentuk Sajian Representasi Simbolik pada Soal

Pemaknaan simbol kurang diperhatikan oleh mahasiswa. Mahasiswa seringkali mengabaikan simbol-simbol, padahal representasi simbol yang benar bermanfaat untuk menyelesaikan masalah matematis lainnya (Fardillah, 2017).

\section{SIMPULAN}

Berdasarkan temuan-temuan di atas, mahasiswa kurang mampu dalam merepresentasikan simbol matematis turunan parsial sebagai metonymy. Hal ini disebabkan karena mahasiswa kurang memahami pentingnya penulisan simbol matematika yang baik dan benar. Mahasiswa menganggap bahwa hasil akhir penyelesaian soal lebih penting dibandingkan dengan memperhatikan simbol matematisnya. Dalam hal memaknai simbol, mahasiswa mampu dalam merepresentasikan simbol turunan parsial sebagai metaphor. Mahasiswa memahami makna turunan parsial fungsi $f(x, y)$ terhadap $x$ yaitu melalui posedur turunan parsial terhadap $x$ dan menganggap $y$ sebagai konstanta. Demikian pula saat melakukan turunan parsial terhadap $y$ dan menganggap $x$ sebagai konstanta. Walaupun masih terdapat kesalahan representasi simbol turunan parsial sebagai metonymy dan kurang teliti melakukan operasi aljabar.

Penelitian selanjutnya disarankan untuk mengembangkan bahan ajar bercirikan representasi simbolik agar mahasiswa dapat memahami penggunaan simbol-simbol matematika yang baik dan benar sebagai metonymy maupun metaphor.

JINoP (Jurnal Inovasi Pembelajaran),Volume 5, Nomor 2, November 2019, hal 214-226 


\section{DAFTAR PUSTAKA}

Arvianto, I. R. (2017). Kesalahan Mahasiswa dalam Menyelesaikan Soal Integral Berdasarkan Gaya Kognitif pada Mata Kuliah Matematika Informatika. JMPM: Jurnal Matematika Dan Pendidikan Matematika, 2(1), 36. https://doi.org/10.26594/jmpm.v2i1.799

Astuti, E. P. (2017). Representasi Matematis Mahasiswa Calon Guru dalam Menyelesaikan Masalah Matematika. Beta Jurnal Tadris Matematika. https://doi.org/10.20414/betajtm.v10i1.100

Fardillah, F. (2017). Kemampuan Representasi Matematis Mahasiswa melalui Pembelajaran Cognitive Apperticeship. JPPM, 10(2), 177-181.

Hutagaol, K. (2013). Pembelajaran Kontekstual untuk Meningkatkan Kemampuan Representasi Matematis Siswa Sekolah Menengah Pertama. Infinity Journal. https://doi.org/10.22460/infinity.v2i1.27

Jitendra, A. K., Nelson, G., Pulles, S. M., Kiss, A. J., \& Houseworth, J. (2016). Is mathematical representation of problems an evidence-based strategy for students with mathematics difficulties? Exceptional Children. https://doi.org/10.1177/0014402915625062

Julca-Aguilar, F., Hirata, N. S. T., Viard-Gaudin, C., Mouchere, H., \& Medjkoune, S. (2014). Mathematical Symbol Hypothesis Recognition with Rejection Option. Proceedings of International Conference on Frontiers in Handwriting Recognition, ICFHR. https://doi.org/10.1109/ICFHR.2014.90

Leibovich, T., \& Ansari, D. (2016). The Symbol-Grounding Problem in Numerical Cognition: A Review of Theory, Evidence, and Outstanding Questions. Canadian Journal of Experimental Psychology. https://doi.org/10.1037/cep0000070

Lestari, K. E., \& Yudhanegara, M. R. (2017). Analisis Kemampuan Representasi Matematis Mahasiswa pada Mata Kuliah Geometri Transformasi Berdasarkan Latar Belakang Pendidikan Menengah. Jurnal Matematika Integratif, 28-33. https://doi.org/10.24198/jmi.v13.n1.11410.29-34

Malviya, S. (2019). Symbol as Metonymy and Metaphor: A Sociological Perspective on Mathematical Symbolism. Science, Technology \& Society, 
24(1), 53-72. https://doi.org/10.1177/0971721818821798

Mandasari, N. (2018). Elaborasi Kognitif dalam Proses Abstraksi Konsep Matematika. 399-405. Palembang.

Presmeg, N. C. (2013). Mathematical Reasoning Analogies, Metaphors, and Images (L. D.English, ed.). London: Taylor and Francis Group.

Sabirin, M. (2014). Representasi dalam Pembelajaran Matematika. Jurnal Pendidikan Matematika. https://doi.org/10.18592/jpm.v1i2.49

Stalnaker, D., \& Zanibbi, R. (2015). Math expression retrieval using an inverted index over symbol pairs. Document Recognition and Retrieval XXII. https://doi.org/10.1117/12.2074084

Suryana, A. (2012). Kemampuan Berpikir Matematis Tingkat Lanjut (Advanced Mathematical Thinking) dalam Mata Kuliah Statistika Matematika 1. (November), 978-979. Yogyakarta. 